\title{
Peculiarities of development of the black poplar (pópulus nígra) in different forestry conditions, Middle Volga, Russia
}

\author{
Natalia M. Trots ${ }^{1, *}$, Vasily B. Trots ${ }^{1}$, Sergey V. Obuschenko ${ }^{1}$, Dmitry A. Akhmatov ${ }^{1}$, and Rishat R. Abdulvaleev ${ }^{2}$ \\ ${ }^{1}$ Samara Agrarian University, 446442 Kinel, Samara region, Russia \\ ${ }^{2}$ Aksenovsky Agricultural College, 452135 Kim village, Republic of Bashkortostan, Russia
}

\begin{abstract}
The regularities of growth and development of black poplar in various plantings and forest growing conditions are revealed. It is established that the highest tree stands of black poplar are on average $30 \mathrm{~m}$. With a trunk diameter of $44 \mathrm{~cm}$, a class I bonitet, a fullness of the studied rock in a stands of 0,5 and a stock of wood per 1 ha of $206 \mathrm{~m}^{3}$ are formed in the nettle. The black poplars that grow in the oak forests of the trees have the lowest productivity. The height of the trees and the diameter of the trunks in these forest conditions are on average 42,1-57,0 \% and 1,6-1,8 times less, respectively, than the stands formed in the nettle and the pine-shrub pine forests, as well as by 31,5 and $33,3 \%$ of the trees growing in vegetation near the riverside. The black poplar quality class in this type of forest is IV, and the stock of raw wood per 1 ha was only $54 \mathrm{~m}^{3}$, with the standing tree of the studied species of 0,4 .
\end{abstract}

\section{Introduction}

In recent years, interest in black poplar on the part of landscapers has significantly decreased, the reason for this is the ability of poplar to form a significant amount of seeds covered with downy formations that fly over considerable distances and litter the streets of cities and towns. This causes an uncomfortable condition and allergic reactions in many people; besides poplar fluff is a source of fire hazard. But at the same time, according to many foresters, black poplar has more advantages than disadvantages, and due to proper selection of the territory for poplar plantings, the disadvantages of this species can be significantly reduced [1-6].

The purpose of research is to study the peculiarities of the formation of black poplar stands (Pópulus nigra) in various forest growing conditions of the Kinel forestry.

In accordance with this, the research tasks included:

1. study of the formation of black poplar plantations in forestry;

2. determination of the main taxation parameters of black poplar in different plantations;

3. identification of the most favorable forest conditions for black poplar in the forestry;

We summarize the results, draw appropriate conclusions and make suggestions for production.

\section{Materials and methods}

Studies were conducted in the period of 2014-2017 in forest plantations of GKU SO "Samara forest areas" Kinel forest area in the forest reserves of Kinel district forestry located in the central soil-climatic zone of the
Samara region within the borders of Kinelsky municipal district.

\subsection{Study object}

The object of the research was the stand of black poplar growing in the following forest conditions:

1. Oak-shrubby pine forests (OSPF) occupying low, even areas with gray forest or chernozem soils of clay or loamy texture. With grassy vegetation represented by: goutweed, forest reedgrass, forest bracken, golden rod, lily of the valley, Solomon's seal, etc.

2. Nettle black poplar stands (NBPS) located in floodplains of prolonged flooding and on floodplain terraces with soddy alluvial soils of silt-sand texture formed on silty loamy and sandy loam sediments. With grassy vegetation represented by nettles, blackberries, canary grass, hop, purple moor-grass, tufted fescue, wood horsetail, etc.

3. Maple-blackberry oakeries (MBO) located on moderate ridges and lower floodplain terraces with soddy alluvial soils, as well as dark gray soils, loamy texture with silty interlayers. Grassy vegetation is represented by: nettle, sedge, horsetail, meadowsweet, hop, spring pea, hedge woundwort, etc.

4. Goutweed oakeries (GWO): flat degradations and mild slopes occupying the thalwegs of gullies, with a soil cover represented by ordinary chernozem, podzolized chernozem and gray forest soils with loamy texture. Grassy vegetation is mainly represented by baneberry, goutweed, blue bugle, yellow archangel, beadruby, nodding melic, Paris herb, nettle and others. Shrub vegetation is represented by hazel, warted spindle wood, viburnum, etc.

* Corresponding author: troz_shi@mail.ru 
5. Riverbed willow woods (RWW) located in low places of the riverbed floodplain on alluvial silty-sandy and sandy sediments with silty interlayers. The grassy vegetation of such sites is represented by: reed grass, angelica, blackberry, nettle, hop, wood horsetail, etc. The following shrubs grow here: buckthorn, brier, etc.

6. Riverbed willowstands (RWS) occupying the lower floodplain terraces of long-term flooding with alluvial sandy and silty soils. Grassy companions of woody vegetation in such conditions are: nettle, ground ivy, hop, blackberries, marsh cinquefoil, marsh horsetail. The shrubs are presented by purple osiers.

\subsection{Study Area Conditions}

The climate of the studied area is typically continental. The annual rainfall is $350-400 \mathrm{~mm}$. The average annual air temperature is $3.2-3.6{ }^{\circ} \mathrm{C}$. The sum of active temperatures is $2500-2600{ }^{\circ} \mathrm{C}$.

Hydrothermal coefficient is $0.8-0.9$. The reserves of productive moisture in the soil in the spring are $125-150 \mathrm{~mm}$. There are 49-64 days of dry wind per year. The duration of the frost-free period is 144-152 days. The predominant soils are leached and typical chernozems of medium-humus and medium-capacity, ordinary chernozems of medium and low humus.

\subsection{Taxation measurements}

When carrying out the research, we used materials from the taxation description of the forests of the Kinel forestry section performed by FSUE "Roslesinforg" Vyatka branch of the state forest inventory and a branch of FSUE "Roslesinforg" (Kirov, 2014). In addition, we also carried out taxation measurements of the height, diameter and completeness of the stands on trial plots of $50 \times 50 \mathrm{~m}$ in size, which were distinguished in each plantation of the vegetation conditions under study. The height of the trees was measured with a Makarov pendulum altimeter, the diameter of the trunks was measured with a fork at a height of $1.3 \mathrm{~m}$, the fullness of the stands was measured with Bitterlich's angle gauge. To do this, at each trial site, two circular control sites were laid from the center of which the sighting was conducted on the diameters (at chest height) of the surrounding trees. The cross-sectional area of each tree, the diameter of which overlapped the nozzle slot (angle of sight), was taken as $1 \mathrm{~m}^{2}$, and the slot was precisely closed $-0.5 \mathrm{~m}^{2}$. The remaining trees were not counted. The number of trees counted was taken as the sum of the cross-sectional areas of trunks per 1 ha in $\mathrm{m}^{2}$. Subsequently, the recalculated number of the crosssectional areas of the plantation trunks was carried out according to the standard reference taxation tables of $\mathrm{N}$. V. Tretyakov. With the help of taxation tables, the stock of wood in terms of 1 ha was also determined.

\section{Results and discussion}

Cameral analysis of taxation description data and our observations showed that black poplar in forestry conditions most often, in natural plantations, can grow as part of mixed stands together with white poplar (Pópulus álba), willow (Salix alba L), white birch (Betula pendula Roth.), low-stemmed elm (Úlmus), and maple (Ácer negúndo) pure form. Such stands are usually confined to the banks of rivers, lakes and natural depressions. At the same time, the stock of black poplar wood in plantations can vary from 30 to $100 \%$ (table 1 ).

Table 1. Composition and taxation indicators of black poplar stands.

\begin{tabular}{|c|c|c|c|c|c|}
\hline $\begin{array}{c}\text { Stand } \\
\text { composition }\end{array}$ & $\begin{array}{l}\text { Wood } \\
\text { species }\end{array}$ & $\begin{array}{l}\text { Age, } \\
\text { years }\end{array}$ & $\begin{array}{l}\text { Height, } \\
\mathrm{m}\end{array}$ & $\begin{array}{l}\text { Diamet } \\
\text { er, cm }\end{array}$ & $\begin{array}{l}\text { Forest } \\
\text { yield, } \\
\mathrm{m}^{3} / \mathrm{ha}\end{array}$ \\
\hline \multirow{4}{*}{$\begin{array}{l}7 \text { white poplar } \\
\text { (WP) } \\
3 \text { black poplar } \\
\text { (BP) + white } \\
\text { willow (WW) } \\
\text { + birch (B) }\end{array}$} & WP & 40 & 23 & 28 & 162 \\
\hline & $\mathrm{BP}$ & 40 & 23 & 28 & 69 \\
\hline & WW & 30 & 10 & 10 & 8 \\
\hline & B & 30 & 10 & 8 & 6 \\
\hline \multirow{4}{*}{$\begin{array}{c}6 \text { birch (B) } 3 \\
\text { black poplar } \\
\text { (BP) } 1 \text { ash- } \\
\text { leaved maple } \\
\text { (ALM) + low- } \\
\text { stemmed oak } \\
\text { (LSO) }\end{array}$} & B & 20 & 12 & 16 & 55 \\
\hline & BP & 20 & 17 & 22 & 27 \\
\hline & ALM & 15 & 8 & 10 & 9 \\
\hline & LSO & 40 & 20 & 20 & 8 \\
\hline \multirow{4}{*}{$\begin{array}{l}5 \text { black poplar } \\
\text { (BP) } 3 \text { white } \\
\text { poplar (WP) } 1 \\
\text { white willow } \\
\text { (WW) } 1 \text { elm } \\
\text { (E) }\end{array}$} & BP & 45 & 25 & 32 & 130 \\
\hline & WP & 45 & 25 & 30 & 80 \\
\hline & WW & 45 & 24 & 28 & 30 \\
\hline & $\mathrm{E}$ & 45 & 18 & 22 & 20 \\
\hline \multirow{2}{*}{$\begin{array}{c}10 \text { black } \\
\text { poplar }(B P)+ \\
\text { elm }(E)\end{array}$} & BP & 62 & 24 & 28 & 188 \\
\hline & E & 30 & 15 & 18 & 10 \\
\hline \multirow{3}{*}{$\begin{array}{l}7 \text { black poplar } \\
\text { (BP) } 2 \text { elm } \\
\text { (E) } 1 \text { low- } \\
\text { stemmed oak } \\
\text { (LSO) }\end{array}$} & BP & 55 & 22 & 28 & 120 \\
\hline & $\mathrm{E}$ & 55 & 20 & 22 & 50 \\
\hline & LSO & 55 & 14 & 28 & 10 \\
\hline
\end{tabular}

In plantations with a $30 \%$ share of black poplar, the main species is hanging birch, occupying up to $60 \%$ in the stock of wood per $1 \mathrm{ha}$, or $55 \mathrm{~m}^{3}$. In addition to these species, the stand is maple with a share of $10 \%$ or 9 $\mathrm{m}^{3} / \mathrm{ha}$ and single oaks with a margin of less than $10 \%$ and the total amount of raw wood per 1 ha $8 \mathrm{~m}^{3}$. The form of such a stand is clearly expressed as 4-tier. In the upper tier there were crowns of low-stem oak reaching $20 \mathrm{~m}$. In the second tier there were black poplar crowns up to $17 \mathrm{~m}$.

The age of the trees in the plantation is different. The oldest trees were low-stem oak trees; their age was estimated at 40 years. Hanging birch and black poplar settled this territory almost simultaneously - about 20 years ago. The leaf-maple appeared relatively recently 8 years ago. In such a stand, the diameter of the trunks also differed. The thickest trunks were in oak $-20 \mathrm{~cm}$ and black poplar $-22 \mathrm{~cm}$. The average diameter of the 
trunks of birch was $16 \mathrm{~cm}$, and of the leaf maple -10 $\mathrm{cm}$. The fullness of the stand was $0.60-0.65$.

This type of forest was obviously formed on the site of former oak stands partially cut down as a result of selective sanitary felling or died under the influence of changing environmental factors, in particular, flooding of the depressed part of the relief by flood waters or rising groundwater. At the same time, the settlement of the territory with new forest-forming species occurred in stages, with an interval of 15-20 years. Individual oak trees survived due to regrowth from a stump. Then, there was a dispersal of birch and black poplar seeds, and subsequently - of ash-leaved maple seeds.

The second, fairly common, type of planting with a $30 \%$ share of black poplar is forest stands, about $70 \%$ of the stock of raw wood accounts for white poplar and only $30 \%$ for black poplar. Along with these poplars, some white willow and birch trees grow, their share in the timber stock is less than $10 \%$. The age of the poplars in such a plantation is about 40 years old, white willow and silver birch - about 30 years.

This type of planting is most often found along the banks of rivers and streams, on pre-river terraces and in natural relief depressions. White poplar and black poplar were probably the first wood species to occupy these areas. It is even possible that they were created with human help, then white willow and silver birch emerged here.

The height of the poplars in this planting is almost equal to $23 \mathrm{~m}$, with a trunk diameter of $28 \mathrm{~cm}$. The crown of white and hanging birch trees extends to $10 \mathrm{~m}$, and the diameter of the trunks is $10 \mathrm{~cm}$ and $8 \mathrm{~cm}$, respectively. The total timber stock per 1 ha is $245 \mathrm{~m}^{3}$. At the same time, the share of white poplar accounts for $162 \mathrm{~m}^{3} /$ ha, black poplar $-69 \mathrm{~m}^{3} / \mathrm{ha}$, white willow -8 $\mathrm{m}^{3} / \mathrm{ha}$, and hung birch is $6 \mathrm{~m}^{3} / \mathrm{ha}$. The relative completeness of such plantations is $0.60-0.73$.

In stands where black poplar occupies about $50 \%$ along with it grows and forms a stock of wood within $30 \%$ - white poplar, $10 \%$ - white willow, $10 \%$ - elm. At the same time, the age of black poplar is about 40 years; white poplar, willow white and elm have about the same age.

Probably, these stands were formed in one time period along the former riverbeds and abandoned loops of the rivers. The river probably changed the streamway as a result of the erosion of soil and rock erosion products. Subsequently, dispersed seeds of the mentioned wood species sprouted up on these deposits.

The form of the stand of such community is complex and has two clearly distinguishable layers. In the upper, or main layer, there are the crowns of black and white poplar, as well as white willow. In the lower layer, there are the crowns of elm.

The average height of black poplar is about $25 \mathrm{~m}$, with a trunk diameter of $32 \mathrm{~cm}$. The crowns of white poplar also extend to a height of $25 \mathrm{~m}$ and are in the same layer with black poplar. The average diameter of its trunk is $30 \mathrm{~cm}$, which is only $6.6 \%$ less than the diameter of the trunk of the main species. The forest yield of black poplar per 1 ha is relatively small and equals to $130 \mathrm{~m}^{3}$, of white poplar $-80 \mathrm{~m}^{3}$.
The height of the elm crown occupies up to $18 \mathrm{~m}$ of above-ground space, with a trunk diameter of $22 \mathrm{~cm}$. The forest yield per 1 ha is $20 \mathrm{~m}^{3}$. The total yield of raw wood in such a stand is $260 \mathrm{~m}^{3} / \mathrm{ha}$. The relative density of this stand composition is $0.70-0.75$.

In forest stands with a $70 \%$ share of black poplar, as a rule, elm (about 20\%) and low-stemmed oak (about $10 \%$ ) grow along with it. The age of such forest stand is about 55 years. Apparently, it was formed on the site of a former forest site that had passed clear cutting. This is indicated by the presence of low-stemmed oak, which was formed from the remaining stump of the past oak stand. Black poplar and elm seeds were dispersed onto the cleared area from other parts of the forest.

The stand form in such forest stand had two clearly pronounced layers. In the upper layer, black poplar crowns extended up to a level of $22 \mathrm{~m}$, with an average trunk diameter of $28 \mathrm{~cm}$. Somewhat lower, elm crowns with a trunk diameter of $20 \mathrm{~cm}$ extended up to $20 \mathrm{~m}$. The height difference between these tree species does not exceed 10-22 \%. In accordance with the existing classification, they can be attributed to the upper (main) layer. In the second layer, there were the crowns of pedunculate low-stemmed oak. Its growth in the area was confined to natural light openings formed in the crowns of the main layer. Oak taxation assessment showed that it was clearly oppressed by black poplar and elm. Its crown extended to a height of $14 \mathrm{~m}$ with a trunk diameter of $28 \mathrm{~cm}$.

The total yield of raw wood in the forest stand of this type was $190 \mathrm{~m}^{3} / \mathrm{ha}$. Black poplar accounted for 120 $\mathrm{m}^{3} / \mathrm{ha}$, elm - $50 \mathrm{~m}^{3} / \mathrm{ha}$, and low-stemmed oak - 10 $\mathrm{m}^{3} / \mathrm{ha}$.

In addition, there are stands in the forestry with almost $100 \%$ share of black poplar, where elm is found only in the form of separate trees or small bio-groups with a share of less than $10 \%$ in the total yeild of raw wood per 1 ha. The age of poplar trees in this forest stand is about 62 years. Their height is $24 \mathrm{~m}$ with an average trunk diameter of $28 \mathrm{~cm}$. The forest yield of poplar per 1 ha is $188 \mathrm{~m}^{3}$. Elm appeared in the stand much later, its age does not exceed 30 years. The elm crown is located under the canopy of black poplar and does not rise higher than $15 \mathrm{~m}$, the average trunk diameter is $18 \mathrm{~cm}$, and the forest yield per 1 ha is $10 \mathrm{~m}^{3}$. The relative density of such a stand is $0.56-0.70$.

Thus, we can conclude that black poplar in forestry conditions most often, in natural forest stands, can grow as a part of mixed stands together with white poplar, white willow, silver birch, low-stemmed oak, elm and ash-leaved maple, with a share in the total forest yield per 1 ha from 30 to $70 \%$, as well as in its pure form (100 $\%$ ) with a small admixture of elm. Such stands are usually confined to the banks of rivers, lakes and natural relief depressions. Moreover, its age varies from 40 to 62 years, the trunk height - from 17 to $25 \mathrm{~m}$, the trunk diameter - from 22 to $32 \mathrm{~cm}$, and the yield of raw wood per 1 ha - from 27 to $180 \mathrm{~m}^{3}$.

The taxation measurements were carried out on practically even-aged trees (51-60 years old - one age class - sixth) to control sides of plantings. The studies showed that the most favorable conditions for the growth 
and development of black poplar are formed in the nettle forests (NBPS). They occupy reduced flat areas with grey forest or chernozem soils of clay or loamy texture. The moisture regime and the level of fertility are relatively balanced for black poplar. The average height of the trees on this site was $30 \mathrm{~m}$ with a diameter of $44 \mathrm{~cm}$, which corresponded to the class I of the bonitet scale. The stock of black poplar wood per 1 ha was $206 \mathrm{~m}^{3}$. The relative fullness of the black poplar plantation was 0.6 (Table 2). Comparatively favorable conditions for the growth and development of black poplar have also developed in the oak-shrub pine forests (OSPF), which occupy reduced flat areas with gray forest or chernozem soils of clay or loamy mechanical composition. The average height of the trunks of the 59-year-old poplar in this type of forest was $27 \mathrm{~m}$, and the diameter of the trunks was $40 \mathrm{~cm}$. This is, on average, only $10-11 \%$ less than the number of tree stands formed in the abdomen of the nettles (NBPS). In accordance with the scale of dividing plantings into classes of bonitets, this stand can be attributed to class II of bonitets. The stock of black poplar wood per 1 ha in this type of forest is formed at the level of $168 \mathrm{~m}^{3}$.

Table 2. Effect of forest growing conditions on the taxation indicators of black poplar

\begin{tabular}{|l|c|c|c|c|c|c|}
\hline \multirow{2}{*}{$\begin{array}{c}\text { Taxation } \\
\text { fees } \\
\text { indicators }\end{array}$} & \multicolumn{5}{|c|}{ Types of forest conditions and forest types } \\
\cline { 2 - 7 } & OSPF & NBPS & MBO & GWO & RWW & RWS \\
\hline $\begin{array}{l}\text { Age of } \\
\text { trees, years }\end{array}$ & 59 & 55 & 52 & 58 & 54 & 51 \\
\hline Age class & VI & VI & VI & VI & VI & VI \\
\hline $\begin{array}{l}\text { Trunk } \\
\text { height, m }\end{array}$ & 27 & 30 & 22 & 19 & 22 & 25 \\
\hline $\begin{array}{l}\text { Trunk } \\
\text { diameter, } \\
\text { cm }\end{array}$ & 40 & 44 & 28 & 24 & 26 & 32 \\
\hline $\begin{array}{l}\text { Bonitet } \\
\text { class }\end{array}$ & II & I & III & IV & III & II \\
\hline $\begin{array}{l}\text { Density of } \\
\text { stocking }\end{array}$ & 0.5 & 0.5 & 0.6 & 0.4 & 0.5 & 0.5 \\
\hline $\begin{array}{l}\text { Timber } \\
\text { stock, } \\
\text { m }^{3} / \text { ha }\end{array}$ & 148 & 206 & 135 & 54 & 130 & 136 \\
\hline
\end{tabular}

Quite good growth conditions for black poplar were also formed in the near-bed vegetation (RWS) occupying the lower floodplain terraces of long-term flooding with sand and silty soils. It is obvious that the grassy satellites of woody vegetation contributed to the creation of optimal air and water conditions in these forest conditions: nettle (Urtíca), budra (Glechóma hederácea), hops (Humulus), blackberry (Rubus fruticosus), marsh cinquefoil (Comarum palustre) marsh horsetail ((Equisetum palustre), and shrubs - various types of willow. The height of the black poplar trunks in this plant community was $25 \mathrm{~m}$ with the average diameter of $32 \mathrm{~cm}$. This is respectively 20.0 and $37.5 \%$ less than the value of trees growing in the garden nettle (NBPS) and by $8.0 \%$ and $25.0 \%$ less than trees growing in pine forests of oak-shrubby (OSPF). The class of bonitet was II. The stock of raw wood black poplar per 1 ha was 136 $\mathrm{m}^{3}$, with the trees density of 0.5 .
Approximately equal taxation parameters were noted by us on the control plots of maple-blackberry (MBO) oak forests, located on lower floodplain terraces with soddy alluvial soils, as well as dark gray soils, loamy mechanical composition with silty interlayers and side layers and dark gray soils with loamy interlayers and side layers located in low places near the riverbed floodplain on alluvial silty sandy and sandy sediments with silty layers.

The height of the trees in these forest conditions was $22 \mathrm{~m}$, with a trunk diameter of $28 \mathrm{~cm}$ and $26 \mathrm{~cm}$, respectively. This is on average 22.7-36.3 and 42.8-69.2\% less than the number of forest stands in the abstracted nettles (NBPS) and oak-shrub pine forests (OSPF), but at the same time, on average, 8.3-16.6\% more than indices of goutweed poplar growing in oak forests (GWO).

The quality class of black poplar in these forest conditions was III, and the relative fullness of the stand was $0.5-0.6$. In terms of timber stock - $133 \mathrm{~m}^{3} / \mathrm{ha}$, maple-blackberry oak forests (MBO) looked better. In the willow near the riverbed (RWW), the amount of raw wood of black poplar was estimated at $130 \mathrm{~m}^{3} / \mathrm{ha}$.

Thus, we can conclude that under the conditions of the Kinelsky district forestry, the highest stands of black poplar which are on average $30 \mathrm{~m}$, with a trunk diameter of $44 \mathrm{~cm}$, class I bonitet, the density of the studied species in the forest stand of 0.5 , and a forest yield of $206 \mathrm{~m}^{3}$ per 1 ha are formed in nettle black poplar stands (NBPS).

Black poplars growing in goutweed oakeries (GWO) have minimal low productivity. The height of the trees and the trunk diameter in these forest conditions are, on average, 42.1-57.0\% and 1.6-1.8 times less than the indices of the stands formed in the nettle black poplar stands (NBPS) and oak-shrubby pine forests (OSPF), as well as $31.5 \%$ and $33.3 \%$ less than the indices of the trees growing in riverbed willowstands (RWS). The bonitet class of black poplar in this type of forest is equal to IV, and the yield of raw wood per 1 ha was only 54 $\mathrm{m}^{3}$, with a standing density of the studied tree species of 0.4 .

\section{Conclusion}

Black poplar in Kinel district forestry in natural plantations can grow in the composition of mixed stands together with white poplar, white willow birch, lowstemmed oak, elm and maple, with share in the total timber stock of 1 ha from 30 to $70 \%$, and also in pure form $(100 \%)$ with a small admixture of elm;

The age of black poplar in forest plantations varies from 40 to 62 years, the height of the trunks varies from 17 to $25 \mathrm{~m}$, the diameter of the trunk varies from 22 to $32 \mathrm{~cm}$, and the stock of raw wood per 1 ha is from 27 to $180 \mathrm{~m}^{3}$.

The highest stands of black poplar are, on average, $30 \mathrm{~m}$ with bonitet class I, the fullness of the main species in plantation is 0.6 , and the wood reserves per 1 ha of $206 \mathrm{~m}^{3}$ are formed in the vegetation conditions of common black-nosed meadows. 
The black poplars that grow in the oak forests of the trees (GWO) have the lowest productivity. The height of the trees and the diameter of the trunks in these forest conditions are on average 42.1-57.0 \% and 1.6-1.8 times less, respectively, than the stands formed in the nettle (NBPS) and the pine-shrub pine forests (OSPF), as well as by 31.5 and $33.3 \%$ of the trees growing in vegetation near the riverside (RWS). The blackwood poplar quality class in this type of forest is IV, and the stock of raw wood per 1 ha was only $54 \mathrm{~m}^{3}$, with the standing tree of the studied species at 0.4 .

When creating black poplar plantations, it should be borne in mind that the most productive stands of this breed with a bonitet class I are formed in the vegetation conditions of black-nosed pickled black algae.

\section{Conflict of interest}

The authors declare no conflict of interest

\section{References}

1. V.P. Bobrinev, L.N. Pak, E.A. Banshchikov, Experience in growing black poplar seedlings, Transbaikalia Agricult. Sci. J. 39, 1 (2015)

2. E.V. Morozova, A.P. Iozus Morozova, Specific features of variety testing of species, hybrids and forms of poplars that are promising for protective irrigated and rainfed forest plantings in the conditions of the dry steppe of the Lower Volga region, Advan. in modern natural sci. J. 306, 11-2 (2016)

3. A. Yalatdinova, Geochemical peculiarities of black poplar leaves (Popul nigra L.), EGU General Assemble 2013, 258 (2013)

4. A. Yalaltdinova, Reflection of the process of technogenesis in the elemental composition of the leaves of poplars (Populus nigra L.) on the example of the city of Ust-Kamenogorsk, 2, 154 (2012)

5. L. Rikhvanov, D. Yusupov, N. Baranovskaya, A. Yalaltdinova, Elem. Composit. of poplar foliage as a biogeoch. Indicat. of indust. Specializ. of urban syst., 6, 58 (2015)

6. N. Yalaltdinova, N. Sirina, N. Baranovskaya, Life Syst. in the Agricult. Syst., 95(12), 2544 (2015) 